\title{
Implementasi Metode Midpoint Filter Untuk Mengurangi Noise Pada Citra Bersih
}

\author{
Nurul Fadillah¹, IImi Hasny² \\ ${ }^{1}$ Universitas Samudra \\ e-mail: nurulfadillah@unsam.ac.id \\ ${ }^{2}$ Universitas Samudra \\ e-mail: michi.lollipop09@gmail.com
}

\begin{abstract}
Abstrak
Pengolahan citra digital merupakan proses yang bertujuan untuk memanipulasi dan mengaanalisis citra dengan bantuan komputer. Pengolahan citra berfungsi untuk memperbaiki kualitas suatu gambar dan mengolah informasi yang terdapat pada suatu gambar untuk keperluan pengenalan objek secara otomatis. Kerusakan pada citra digital sering terjadi akibat adanya impulse noise. Midpoint filter biasanya digunakan untuk memfilter gambar yang mengandung noise berekor pendek seperti Gaussian. Midpoint Filter didefinisikan : dimana koordinat $(x+i, y+j)$ didefinisikan di atas gambar $A$ dan koordinat $(1, j)$ didefiniskan di atas persegi ukuran NxN . Secara sederhana filter midpoint bertujuan untuk menghitung titik tengah antara nilai maksimum dan nilai minimum apliaksi perangkat lunak yang mampu menguragi efek noise yang mengganggu pada citra digital dengan menggunakan metode MidPoint Filter.
\end{abstract}

Kata Kunci: Citra, Noise, MidPoint Filter, Gaussian

\section{Abstract}

Digital image processing is a process that aims to manipulate and analyze images with the help of computers. Image processing functions to improve the quality of an image and process information contained in an image for the purpose of object recognition automatically. Damage to digital images often results from impulse noise. Midpoint filters are usually used to filter images that contain short-tailed noise such as Gaussian. The Midpoint Filter is defined: where the coordinates $(x+i, y+j)$ are defined above image $A$ and the coordinates $(1, j)$ are defined on the square of the size of NxN. In simple terms, midpoint filters aim to calculate the midpoint between the maximum value and the minimum value of a software application that is able to reduce the disturbing noise effects on digital images using the MidPoint Filter method.

Keywords: Image, Noise, Midpoint Filter, Gaussian

\section{Pendahuluan}

Pengolahan citra adalah sebuah cabang ilmi yang berakar dari grafika komputer yang menitik beratkan permasalahannya pada peningkatan kualitas citra, perbaikan citra, dan pemeliharaan. Aplikasi-aplikasi seperti fotografi, remote sesoring, sampai dengan multimedia (citra tetap, citra bergerak, audio, san gabungan ketiganya) adalah contoh-contoh aplikasi yang seringkali menggunakan teknik pengolahan citra. Suatu citra terkadang memiliki noise karena citra tersebut salah dalam pengambilan ataupun karena file tersebut memang pada dasarnya kurang baik, noise pada gambar biasanya berbentuk titik yang tersebar diseluruh gambar atau beberapa bagian pada gambar, untuk proses perbaikannya bisa dilakukan dengan menggunakan software-software seperti adobe photoshop ataupun software pengguna citra digital.

Ketika sebuah citra ditangkap oleh kamera, seringkali tidak dapat langsung digunakan sebagaimana diinginkan karena kualitasnya belum memenuhu standar kebutuhan pengolahan. Misalnya saja citra disertai oleh variasi intensitas yang kurang seragam akibat pencahayaan yang tidak merata, atau lemah dalam hal kontras sehingga objek sulit untuk dipisahkan dari latar belakangnya karena terlalu banyak gangguan dalam citra. Secara umum dapat dikatakan bahwa citra yang demikian kualitasnya masih renda, baik oleh karena adanya gangguan dalam citra maupun oleh 
sebab lainnya. Adakalanya citra yang diperoleh dengan cara melukis pada media komputer atau diperoleh dari peralatan kamera digital lainnya terlihat kasar (Alfiant, n.d.).

Reduksi Noise adalah sebuah teknik yang digunakan untuk memperbaiki gambar yang memiliki noise, teknik yang digunakan adalah dengan mengganti pixel noise dengan pixel gambar yang mendekati pixel noise tersebut. Metode MidPoint filter ini mengganti nilai sebuah piksel dengan nilai rata-rata dari piksel terkecil dan nilai piksel terbesar dari gray-level dalam subimage dibawah jendela ketetanggan ukuran MxN. Filtering metupakan kombinasi order statistic dan average. Tools yang akan digunakan adalah apliaksi Matlab 2009 (Kurniawati, 2016).

\section{Metode Penelitian}

Metode penelitian ini secara garis besar digambarkan pada Gambar 2.1. Metodologi penelitian ini merupakan cara yang digunakan untuk melakukan pengamatan dengan pemikiran yang tepat secara terpadu melalui tahapan-tahapan yang disusun secara ilmiah untuk mencari, menyusun serta menganalisis dan menyimpulkan data, sehingga dapaat dipergunakan untuk menemukan mengembangkan dan menguji kebenaran sesuai ilmu pengetahuan.

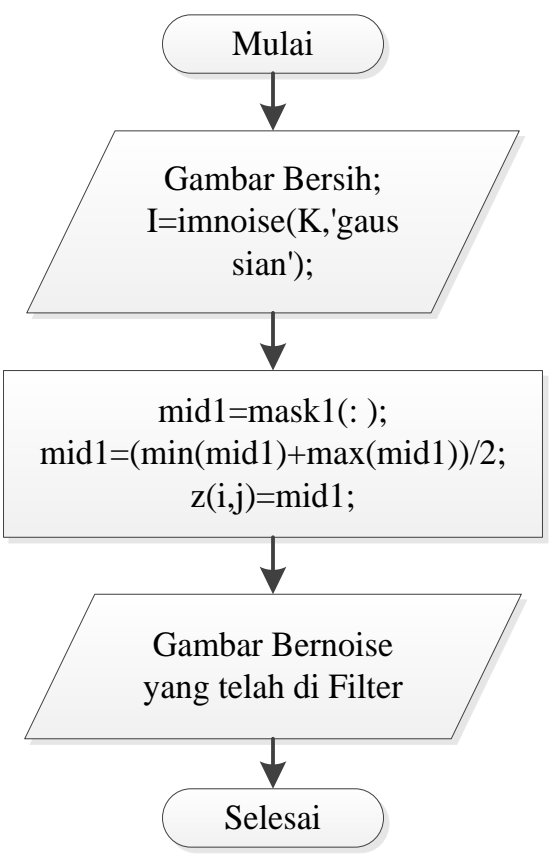

Gambar 1 Flowchart

\section{A. Memasukkan Citra}

Citra merupakan suatu representasi, kemiripan, atau imitasi dari suatu objek atau benda. Penginputan citra dilakukan dengan mengubah data-data citra kedalam bentuk matriks. Data-data atau pengkodean citra ini diubah berdasarkan derajat keabuan(gray scale) sesuai tingkat warna dari pikse-piksel dalm image.

B. Memberikan Noise Pada Gambar Bersih

Setelah melakukan penginputan citra langkah selanjutnya adalah pemberian noise pada citra. Noise yang digunakan dalam penelitian ini adalah noise Gaussian. Untuk menambahkan noise ini pada MatLab memerlukan input tambahan berupa rata-rata dan variasi. Rata-rata dan variasi merupakan suatu konstanta real. Nilainya bisa positif maupun negatif. Makin besar rata-rata dan variasinya maka citra akan semakin kabur, sebaliknya makin kecil konstantanya efel pada citra makin terlihat.

C. Melakukan Filtering pada Citra

Setelah melakukan noise pada citra selanjutnya adalah tahap filtering, pada jurnal ini kami menggunakan filter midpoint filter. Filter ini mengganti nilai sebuah piksel dengan nilai rata-rata dari nilai terkecil dan nilai terbesar dari gray-level dalm sub image.

\section{Hasil Filtering}

Output atau hasil yang akan tampil berupa gambar asli,gambar yang telah diberi noise Gaussian dan gambar yang telah di filtering dengan metode MidPoint filter. Terlihat pada gambar bahwa gambar yang telah difiltering masih banyak noisenya. Metode MidPoint filter ini belum efisien untuk menghilangkan noise gaussian.

\section{E. Penerapan Perhitungan Metode} MidPoint Filter

Tentukan piksel citra yang ingin difiltering. Misalkan:

Tabel 1. Piksel Citra Sebelum di Filtering

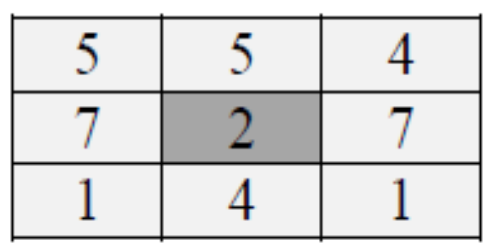


Akan dilakukan filtering terhadap citra yang bernoise dengan mengganti nilai dari titik tengah piksel tersebut.

Langkah yang harus dilakukan adalah:

1. Menentukan nilai piksel maksimu (terbesar) dan minimum (terkecil) untuk mengganti nilai tengah dari piksel.

Diketahui

Niali Max $=7$

Nilai Min $=1$

2. Memasukkan data piksel ke rumus midpiont filter.

$$
\begin{aligned}
& f(x, y)=(\max (p, q)+\min (p, q)) / 2 \\
& f(x, y)=(7+1) / 2 \\
& f(x, y)=8 / 2 \\
& f(x, y)=4
\end{aligned}
$$

3. Mendapatkan hasil filtering noise

Tabel 2. Piksel Citra setelah di filtering

\begin{tabular}{|l|l|l|}
\hline 5 & 5 & 4 \\
\hline 7 & 4 & 7 \\
\hline 1 & 4 & 1 \\
\hline
\end{tabular}

\section{Hasil dan Pembahasan}

Midpoint filter adalah filter yang mencari rata-rata gray level maksimum dan minimum dalam suatu citra yang ditentukan oleh suatu kernel. Dengan kata lain gambar asli akan diberi noise gaussian dna filtering dengan metode midpoint filter yang akan menampilkan efek noise. Munculnya titiktitik berwarna yang jumlahnya sama dengan persentase noise. Metode midpoint filter akan mencari nilai gray leve; maksimum dan minimum dalam suatu citra yang ditentukan oleh suatu kernel. Jadi nilai piksel pada gambar asli diubah dengan nilai tengah dari nilai maksimum dan nilai minimum. Pada output hasil terlihat bahwa metode midpoint filter ini masih kurang sempurna unutk menghilangkan noise gaussian pada gambar bersih.

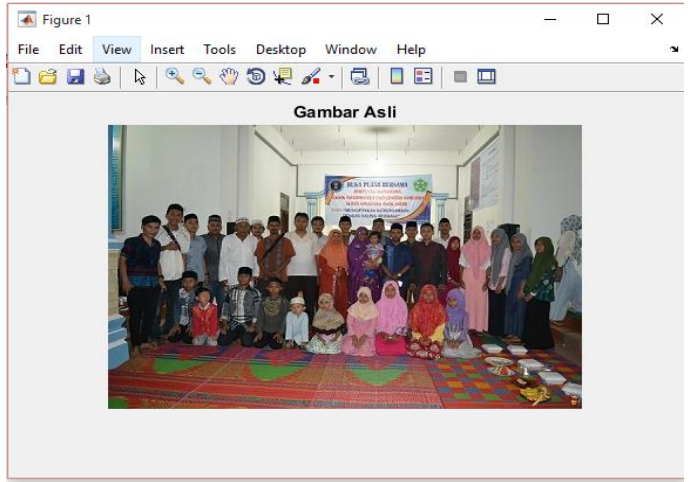

Gambar 2. Memasukkan Citra Asli

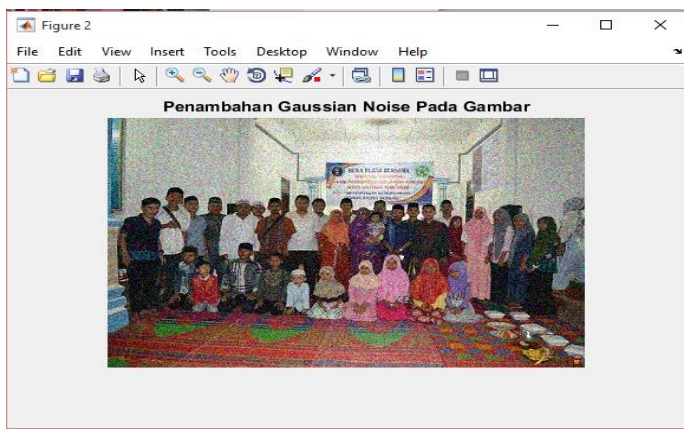

Gambar 3. Citra yang diberi noise Gaussian

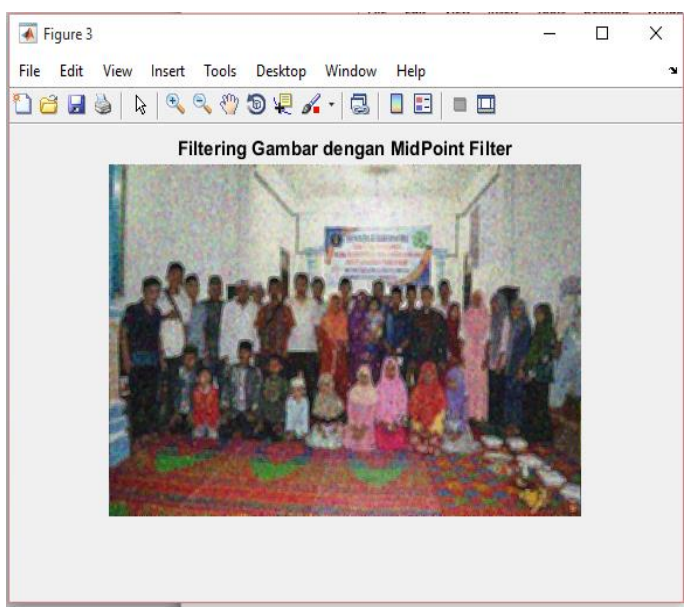

Gambar 4. Gambar yang telah difilter dengan metode MidPoint Filter

\section{Kesimpulan}

Berdasarkan hasil dari reduksi noise pada citra menggunakan midpoint filter, maka dapat disimpulkan bahwa midpoint filter tidak cukup akurat dalam mereduksi noise karena hanya mengganti nilai titik tengahnya saja. Metode mean filter 
dan midpoint filter dapat diterapkan dalam reduksi noise dengan operasi menghitung nilai piksel awal sampai pada piksel akhir gambar.

\section{Referensi}

Alfiant, N. (n.d.). Aplikasi Pengolahan Citra Untuk Mengurangi Efek Noise Dengan Menggunakan Metode Midpoint. 1-5.

Bambang, Yuwono. (2010). Image Smoothing Menggunakan MidPoint Filtering, Median Filtering, Modus Filtering dan Gaussian Filtering. Jurnal Telematika, Vol. 7, No. 1, Juli 2010, hal. 65-75.

Eko, Prasetyo. (2011). "Pengolahan Citra Digital dan Aplikasinya Menggunakan Matlab". Penerbit Andi, ISBN: 978-979-29-2703-0, Yogyakarta.

Gede, I. N., Astawa, A., \& Rudiastari, E. (2018). Perbaikan Citra Wajah Dengan Metode Histogram Equalization Perbaikan Citra Wajah Dengan Metode Histogram, lqbal, M. (2009). "Dasar Pengolahan Citra Menggunakan MATLAB". Departemen IImu dan Teknologi Kelautan. Bogor. Institut Pertanian.

Kurniawati, S. (2016). Perancangan Aplikasi Reduksi Noise Pada Metode Mean Filter Dan Midpoint.

Sandi, O. A., \& Sutojo, T. (n.d.). Perbandingan Kinerja Metode Median Filter Dan Midpoint Filter Untuk Mereduksi Noise Pada Citra Digital, 1-8.

Sholihin, Ricky Aprias. (2013). "Implementasi Median Filter dan Metode Histogram Equalization dalam Perbaikan Citra". Teknik Elektro. Universitas Muhammadiyah Surakarta.

T. Sutoyo, Mulyanto, Edy. 2009. "Teori Pengolahan Citra Digital". Semarang. C.V. Andi Offset

Wedianto, A., Sari, H. L., \& H, Y. S. (2016). Analisa Perbandingan Metode Filter Gaussian , Mean Dan Median Terhadap Reduksi Noise, 12(1), 21-30. 